\title{
A Study of Career Satisfaction Among Estate Surveyors and Valuers in Akwa Ibom State, Nigeria
}

\author{
Okey Nwanekezie $^{1^{*}} \quad$ Stanislaus Okeahialam $^{2}$ \\ 1.Department of Estate Management, University of Uyo, P.M.B. 1017, Uyo, Akwa Ibom State, Nigeria \\ 2.Department of Estate Management, Imo State University, P.M.B. 20401, Owerri, Imo State, Nigeria
}

\begin{abstract}
This study surveyed a cross-section of sixty-five (65) estate surveyors and valuers in both public and private practice to determine their career satisfaction level. Twelve (12) test satisfaction statements were posed to the respondents through a questionnaire. The gathered data were analyzed using relative importance index. The study found that estate surveyors and valuers in public practice were unsatisfied with their career success, while those in private practice showed a higher career satisfaction level. The work advocated for improvement in working condition, income and development opportunities for estate surveyors and valuers in public practice and for improvement in the organizational structure of those in private practice.
\end{abstract}

Keywords: Satisfaction, Career, Estate Surveyors and Valuers, Private Practice, Public Practice.

DOI: $10.7176 / \mathrm{EJBM} / 11-12-02$

Publication date: April $30^{\text {th }} 2019$

\section{Introduction}

Our society is filled with books and programs designed to help individuals discover and achieve their potentials. This is driven by the need to lead a successful life and fulfill one's life dream. Thus, one is often faced with what to do in life. Gambo, Osagie, Salihu, and Ogungbemi (2012) posit that career selection is one of many difficult tasks students are faced with as this determine their future plans and this decision usually affects them throughout their future lives. Some persons may have an idea of what to do in life and would pursue such goals through their choice of course of study and career, while others may not necessarily have such ideas or position. Egbenta (2008) observed that over the years many students gain admission to study Estate Management in Nigerian Universities without understanding what the course entails. Choice of course and career in life may not necessarily guarantee career satisfaction.

Career satisfaction, like happiness, is an inherently subjective measure. For one, it could be measured in terms of compensation, working hours and interest in the work. For another, it is a complex mix of emotional responses that cannot be easily reduced to components. Sokanu (2017) found that there is a weak correlation between salary and satisfaction across all the dimensions of satisfaction. The study also found that people employed in higher paying jobs do not report higher career satisfaction than others.

Woodcock (2017) outlines what would make someone happy at work to include work environment, autonomy and purpose/goals. Whereas for Sokanu (2017) it includes personality, work environment, interest, skill utilization, meaning, and salary. The component of satisfaction by Woodcock (2017) is in a compressed form which if expatiated, can be similar to Sokanu (2017).

According to City and Guilds cited in Woodcock (2017), the happiest graduate jobs include those of the doctor, dentist, armed forces, teachers, leisure and tourism jobs, journalists, accountants, lawyers, public relations and advertising staff, Nurses, Architects, Computing staff, and bankers. While the list of least happy professionals includes social workers, civil servants, estate agents, secretaries, and administrators. Also, Sokanu (2017) reports that careers requiring no formal education are paradoxically the happiest. These findings by city and Guilds is a United States-based study and one wonders if real estate professionals are also the least happy professionals in Nigeria. Studies such as Egbenta (2008) and Gambo et al (2012) have examined students' career selection at the universities, Nwanekezie, Ofekelam and Diala (2009), Oluwunmi, Ajayi, Olaleye and Fagbenle (2011), and Ehiemere, Ogbuefi and Awum (2016) have assessed clients satisfaction with the services of estate surveyor and valuers in Nigeria, while Bamidele and Koleoso (2016) assessed job satisfaction and staff turnover. None of the above studies have assessed career satisfaction among practicing estate surveyors and valuers in Nigeria. This is more relevant given the studies of Egbenta (2008) and Gambo et al (2012) where it was found that most students stumbled on estate management as a course in university without the initial passion to study the course. This coupled with the earlier report that estate agents are among the least happy professionals. Therefore, the goal of this study is to examine career satisfaction among estate surveyors and valuers in both private and public practice in Uyo, Akwa Ibom State, Nigeria.

\section{Review of Related Literature}

Egbenta (2008) in Enugu investigated the factors that influence students' choice of Estate Management in Nigerian universities using University of Nigeria, Nsukka as case study. A Cross-section of 120 final year students from 
two sessions were surveyed out of which 105 questionnaires were returned. The data was analysis using simple frequency tabulation and percentages. The study found that majority of the students came into estate management programme by chance or as a last resort when they could not gain admission for their preferred courses. The findings also showed that majority of those who eventually find themselves in the profession by chance claim to have no regrets for studying the course. The author recommended that prospective students should visit the department or university or the websites of the university and make enquiry about the degree requirements. This study is relevant since it had revealed the perception of students but there is need to investigate their perception and satisfaction level after university life which this present study seek to achieve

In a study of clients satisfaction, Nwanekezie et al (2009) surveyed a cross-section of 500 clients of estate surveyors and valuers in the Niger-Delta region of Nigeria. The resultant data was analyzed using simple percentages, chi-square test, Spearman's rank correlation and mean. The findings showed that the services of professional estate surveyors and valuers was reasonably sought after, though there was a high level of ignorance and lack of awareness of the activities of the profession. The study also revealed that there is significant difference between the quality of the services rendered by estate surveyors and quacks and that there is correlation between quality of service and level of clients satisfaction. It further showed that clients were dissatisfied with some dimensions of services rendered by the estate surveyors. The study recommended aggressive public enlightenment to reduce the menace of quackery.

The focus of this study was on client's satisfaction without considering if the person offering the service is even satisfied and fulfilled.

Araloyin and Ojo (2011) in Lagos investigated factors contributing to customer's satisfaction and retention in real estate agency firms. The study used a questionnaire to obtain information from 203 clients of estate firms in Lagos. Simple percentage and relative importance index were used to analyze the gathered data. The study found that the most important thing affecting the quality of service of the real estate agent in the perception of the agents' customers is the agent's reputation. The firm's size was found to be the second most important factor followed by regulations governing the behavior of the real estate agents and amount of advertising provided by the estate firm. The study concluded that a reputable real estate agent will have more satisfied clients and attract repeat businesses. The study recommended that real estate agents should create a first good impression as this has a way of affecting their client's opinion and satisfaction. The study did not state the study population and the sampling was not probabilistic in nature, therefore may not be a true representative of estate firm's clients. Besides, it is on factors affecting client's satisfaction without actually measuring the satisfaction level.

In a similar study to Araloyin and Ojo (2011), Araloyin and Ojo (2011) examined real estate consumers' perception of service quality in estate agency in Lagos. A total of 203 real estate service consumers from 118 estate firms were selected and sampled by the authors. Simple percentage and relative importance index were employed to analyze the resultant data. The study found that there are five (5) key components to customers' satisfaction which also has the ability to attract repeated businesses in real estate agency. Like the earlier study, the sampling is not probabilistic and the study population is unknown.

In Lagos, Oluwunmi et al (2011) investigated client's perception of the quality of property valuation report for mortgage purpose and their satisfaction level. A total enumeration survey of the twenty-five (25) head offices of banks in Lagos was conducted in which nineteen (19) responded. Also, the authors examined the contents of 72 valuation reports to determine if they fall short of the standard of Nigerian Institution of Estate Surveyors and Valuers (NIESV). The data were analyzed using percentages and mean. The studies found that majority of the clients (banks) were satisfied with the overall content of the valuation report they received from valuers. It further revealed that the banks would want additional information such as details of tenancies, details on specific comparables, state of letting market, general information on comparables, valuation calculations, and reducing uncertainty about valuation figures in these valuation reports. The study was limited to banks and valuation without considering other types of clients and services of estate surveyors and valuers.

Spurk, Abete and Volmer (2011) in Germany, examined the adequacy of the widely used Career satisfaction Scale (CSS) for measuring change over time. The study surveyed a sample of 1,273 professionals over a 5 years time period and the data were analyzed using multiple indicator latent growth modeling. The study found that the career satisfaction scale can be reliably used in mean change analysis and that career satisfaction was relatively stable over the study period. The study also found that professionals who were initially highly satisfied became less satisfied over time. This study examined so many professionals which may result in unlimited generalization.

Gambo et al (2012) studied students' perception of career choice in Estate Management in Bauchi State. A total of 118 graduating students of Abubakar Tafawa Belewa University, Bauchi were surveyed in the study, and simple percentages were used to analyze the data. The study showed that the students already had a prior knowledge of what the course was all about and it was a choice they made on their own and not based on external influences from either parents or peers. It also revealed that some of the students had to opt for estate management because they could not get admitted into the institution based on their course of the first choice. The findings of this study contradict the findings of Egbenta (2008) where students in University of Nigeria, Nsukka were found 
to stumble into the course. Also, like Egbenta (2008), it has not examined their satisfaction with the course after graduation.

Is'haq, Musa and Bello (2013) in Bauchi evaluated the satisfaction of Abubakar Tafawa Belewa University's staff with the property management services provided by the works and services unit of the university. A Crosssection of 38 staff of school of Environmental Technology of the university was surveyed using SERVQUAL framework questionnaires. The resultant data were analyzed using t-test statistics. The study found that there is a significant gap between the respondent's service expectation and actual service encountered across the entire service dimension framework on the property management services provided by the university. The authors recommended urgent attention from the management of the university to address the issue, as staff satisfaction with their work environment is a factor that contributes to the achievement of the university's mission and vision. This paper did not state the study population or the basis of choosing the school of environmental technology as the only school to survey, thus its finding cannot be said to represent the view of staff of the university.

In Lagos, Bamidele and Koteoso (2016) examined the influence of job satisfaction factors on turnover of estate surveyors and valuers. 179 respondents were surveyed using stratified random sampling technique and data were analyzed using frequency distribution, percentage, mean score, and ANOVA. The study found that timely remuneration, feedback to employees, creating opportunities to enhance professional knowledge, equitable company promotion policy and ability to learn from co-workers were the factors which mostly encouraged the respondents to stay at their jobs. It also revealed that all the job satisfaction factors (payment, supervision, work condition, promotion and interrelationship with co-workers) have an equal effect on the respondents' job retention. The findings of this study are relevant being the only paper that has assessed the satisfaction of staff in estate firms but did not examine the head of practice of the estate firms which would have given a holistic view of carrier satisfaction of practicing estate surveyors and valuers. This paper shall attempt to fill this gap.

\section{Research Methodology}

This study sought to measure the level of career satisfaction among estate surveyors and valuers in Akwa Ibom State. Previous studies have examined either students' perception of estate management course at tertiary institutions or job satisfaction among those working in estate firms.

The records of Nigerian Institution of Estate Surveyors and Valuers, Akwa Ibom State branch shows that there are sixty-five (65) registered estate surveyors and valuers in Akwa Ibom State in both public and private sectors. There are thirty-six (36) private practitioners of Estate surveying and valuation, while twenty-nine (29) are in public practice. Total enumeration survey of the sixty-five (65) registered estate surveyors and valuers was conducted. Twenty-eight (28) private practitioners representing $77.77 \%$ responded positively, while in public practice twenty-three (23) representing79.31\% responses were received and analyzed. Twelve (12) items/statements that test satisfaction level was posed to the respondents on a Likert scale. Relative satisfaction index was employed to analyze the resultant data.

\section{Results and Discussion}

Data gathered from the field survey is presented and discussed in this section. Literature has identified several satisfaction questions, and the respondents were asked to agree or disagree with each of the statements. Strongly agree is graded 5, while strongly disagree is ranked I. Their responses and analysis thereof are shown in table 1 and 2 .

The responses of the public practitioners are presented in table 1 below. They were required to agree or disagree with each of the statements. 
Table I: Career Satisfaction of Estate Surveyors and Valuers in Public Practice

\begin{tabular}{|l|l|l|l|l|l|l|l|l|}
\hline S/No & \multicolumn{1}{|c|}{ Item/Statement } & $\begin{array}{l}\text { SP } \\
(\mathbf{1})\end{array}$ & $\begin{array}{l}\text { T } \\
(\mathbf{2})\end{array}$ & $\begin{array}{l}\text { UD } \\
\mathbf{( 3 )}\end{array}$ & $\begin{array}{l}\mathbf{A} \\
\mathbf{( 4 )}\end{array}$ & $\begin{array}{l}\text { SA } \\
\mathbf{( 5 )}\end{array}$ & \multicolumn{1}{|c|}{ RI } & Rank \\
\hline 1. & My work has helped me achieve success in my career & 1 & 5 & 12 & 3 & 2 & 3.00 & $5^{\text {th }}$ \\
\hline 2. & $\begin{array}{l}\text { I feel like I have made sufficient progress in meeting my } \\
\text { overall career goals. }\end{array}$ & 1 & 5 & 11 & 4 & 2 & 3.04 & 4 th \\
\hline 3. & $\begin{array}{l}\text { I think I have made progress in meeting my goals for } \\
\text { income. }\end{array}$ & 2 & 8 & 9 & 3 & 1 & 2.69 & $7^{\text {th }}$ \\
\hline 4. & $\begin{array}{l}\text { My work has allowed me to make progress in meeting my } \\
\text { goal for advancement. }\end{array}$ & 1 & 8 & 10 & 4 & 0 & 2.65 & $8^{\text {th }}$ \\
\hline 5. & My work has allowed development of new skills & 2 & 5 & 12 & 2 & 2 & 2.87 & $6^{\text {th }}$ \\
\hline 6. & My working hours are convenient. & 0 & 3 & 11 & 7 & 2 & 3.35 & $2^{\text {nd }}$ \\
\hline 7. & The organizational structure allows for growth. & 0 & 2 & 3 & 13 & 5 & 4.00 & $1^{\text {st }}$ \\
\hline 8. & My working condition is appealing and suitable & 2 & 4 & 10 & 4 & 3 & 3.09 & $3^{\text {rd }}$ \\
\hline 9. & I feel like I have utilized my full skills and potential. & 5 & 9 & 7 & 1 & 1 & 2.30 & $11^{\text {th }}$ \\
\hline 10. & I find my work interesting & 3 & 8 & 10 & 1 & 1 & 2.52 & $10^{\text {th }}$ \\
\hline 11. & My work allows for creativity and/or control & 4 & 7 & 8 & 3 & 1 & 2.57 & $9^{\text {th }}$ \\
\hline 12. & I look forward to going to work & 2 & 6 & 10 & 3 & 2 & 2.87 & $6^{\text {th }}$ \\
\hline & Overall & 23 & 70 & 113 & 48 & 22 & 2.91 & \\
\hline
\end{tabular}

Source: Author's field survey

An examination of the above table 1 shows that only five (5) items are significant or satisfactory. Organization structure of the various government institutions where estate surveyors work is ranked highest with an index of 4.00 and followed by working hours with an index of 3.35. This means that estate surveyors in the employ of government are quite satisfied with the organization structure and their working hours. Also satisfactorily ranked is the working condition with an index of 3.09, while in the fourth and fifth positions are "my work has helped me achieve success in my career" and" I feel like I have made sufficient progress in meeting my overall career goals" with indices of 3.04 and 3.00 respectively. In a tied, insignificant and unsatisfactory position with indices of 2.87 each are "my work has allowed development of new skills and "I look forward to going to work". This means that the respondents are satisfied with the level of development of new skill and may not be excited about the idea of going to work. The respondents were also unsatisfied with the progress they had made with income and meeting their goal for advancement. The respondents did not find their work interesting and felt like they have not fully utilized their skills and potentials. The overall index shows the respondents were unsatisfied with their career as public servants. This means though they were satisfied with few components of their career but generally they were quite unsatisfied with the career. Egbenta (2008) and Gambo et al (2012) had early reported students of estate management course studying the discipline by chance, it follows also that they could be unsatisfied practicing such professions. Bamidele and Koteoso (2016) found that payment, work condition, and promotion have an effect on job retention by estate surveyors and the respondents in this study were unsatisfied with their income and other critical components.

Next, the responses of estate surveyors and valuers in private practice, majority being heads of practice of the various firms are presented in table 2 below. The same statements were posed to them and their opinion is analyzed using relative importance index. 
Table 2: Career Satisfaction of Estate Surveyors and Valuers in Public Practice

\begin{tabular}{|l|l|l|l|l|l|l|l|l|}
\hline S/No & Item/Statement & $\begin{array}{l}\mathbf{S P} \\
(\mathbf{1})\end{array}$ & $\begin{array}{l}\mathbf{T} \\
\mathbf{( 2 )}\end{array}$ & $\begin{array}{l}\mathbf{U D} \\
\mathbf{( 3 )}\end{array}$ & $\begin{array}{c}\mathbf{A} \\
\mathbf{( 4 )}\end{array}$ & $\begin{array}{l}\text { SA } \\
\mathbf{( 5 )}\end{array}$ & $\mathbf{R \Pi}$ & rank \\
\hline 1. & My work has helped me achieve success in my career & 1 & 2 & 14 & 9 & 2 & 3.33 & $5^{\text {th }}$ \\
\hline 2. & $\begin{array}{l}\text { I feel like I have made sufficient progress in meeting my } \\
\text { overall career goals. }\end{array}$ & 1 & 4 & 15 & 5 & 3 & 3.19 & 6 th \\
\hline 3. & $\begin{array}{l}\text { I think I have made progress in meeting my goals for } \\
\text { income. }\end{array}$ & 0 & 1 & 13 & 10 & 3 & $3 . .43$ & 3 th \\
\hline 4. & $\begin{array}{l}\text { My work has allowed me to make progress in meeting my } \\
\text { goal for advancement. }\end{array}$ & 1 & 12 & 9 & 4 & 3.46 & 2 th \\
\hline 5. & My work has allowed development of new skills & 1 & 5 & 15 & 4 & 3 & 3.11 & 8 th \\
\hline 6. & My working hours are convenient. & 1 & 3 & 14 & 7 & 4 & 3.46 & $2^{\text {nd }}$ \\
\hline 7. & The organizational structure allows for growth. & 3 & 5 & 13 & 6 & 1 & 2.89 & $9^{\text {st }}$ \\
\hline 8. & My working condition is appealing and suitable & 2 & 2 & 16 & 6 & 2 & 3.14 & $7^{\text {rd }}$ \\
\hline 9. & I feel like I have utilized my full skills and potential. & 1 & 2 & 13 & 8 & 4 & 3.43 & $3^{\text {th }}$ \\
\hline 10. & I find my work interesting & 0 & 4 & 9 & 10 & 5 & 3.39 & $4^{\text {th }}$ \\
\hline 11. & My work allows for creativity and/or control & 0 & 3 & 17 & 4 & 4 & 3.32 & $5^{\text {th }}$ \\
\hline 12. & I look forward to going to work & 0 & 1 & 10 & 12 & 5 & 3.75 & $1^{\text {th }}$ \\
\hline & Overall & 11 & 34 & 161 & 90 & 40 & 3.34 & \\
\hline
\end{tabular}

Source: Author's field survey

Data in table 2 above reveals that estate surveyors in private practice have career satisfaction with overall index of 3.34. Only organization structure has an index of 2.89 which is insignificant. This means that the respondents are unsatisfied with the organizational structure in private practice which do not allow for growth. This could be evidenced in the rate at which registered estate surveyors and valuers opened their practice once they are registered. The urge to go to work is ranked highest with an index of 3.75 followed by ability for advancement and convenience of working hours with indices of 3.46 respectively in tied second position. Also tied third position with indices of 3.43 each are ability of meeting goals for income target and utilization of skills and potentials. The respondents also found their work interesting and were equally satisfied with the success they have achieved in their career. They further expressed satisfaction of creativity and control exercised by them within their work and progress made in meeting their overall career goals. The satisfaction level of respondents in private practice is contradicted by the satisfaction level of those in public practice. While the findings from public practitioners collaborates the research findings of city and Guilds, that of private practitioners contradicts. It is also worth noting that private practitioners are satisfied with their career which collaborates the findings of Sokanu (2017) where self-employed individuals were found to be happier.

\section{Conclusion and Recommendation}

This paper has examined career satisfaction among practicing estate surveyors and valuers in Akwa Ibom State. The study concluded that estate surveyors working in public institutions were less satisfied with their overall career growth and achievement. While those in private practice were quite satisfied with their overall career growth and achievement. Almost all the estate surveyors in private practice are self-employed which generate some sort of self-fulfillment hence their satisfaction level.

Improvement on working condition, income and opportunities for development will help increase the career satisfaction of the estate surveyors in public practice. The private practitioners could help in restructuring their organizational structure to allow younger surveyors growth through the ranks. This will encourage partnership rather than the existing one-man practice as is prevalent today. Further researches in this area of career satisfaction among estate surveyors and Valuers in other states and region of the country is expedient to have a holistic view of the satisfaction level.

\section{References}

Araloyin, F.M. and Ojo, O. (2011). An Analysis of Real Estate Consumers' Perception of Service Quality in Estate Agency Practice in Lagos Metropolis, Nigeria. Journal of Economics and International Finance, 3(3): 139145.

Araloyin, F.M. and Ojo, O. (2011). Factors Affecting the Provision of Quality Service in Real Estate Agency in Lagos Metropolis, Nigeria. International Journal of Business Administration. 2(1): 71-79.

Bamidele, A.O. and Koleoso, H.A. (2016). Job Satisfaction and Staff Turnover of Estate Surveyors and Valuers in Lagos State. Lagos Journal of Environmental Studies, 8 (1): 1-12.

Egbenta, I. (2008). A Career Choice in Estate Management: A study of Students Perception in the University of Nigeria, Nsukka. The Estate Surveyor and Valuer, 31 (2): 63-69. 
Ehiemere, N.D., Ogbuefi, J.U. and Awum, B. (2016). Customers Satisfaction Amongst Users of Estate Surveyor and Valuation Professional Services. Does Firm Size Matter? ATBU Journal of Environmental Technology, 9(2):72-85.

Gambo, Y.L., Osagie, J.U., Salihu, M.M. and Ogungbemi, A.O. (2012). Students' Perception of Career Choice in Estate Management: A Study of Abubakar Tafawa Belewa University Bauchi, Nigeria. Global Journal of Management and Business Research, 12 (14): 66-72.

Ishaq, M.M., Musa, S.L., and Bello, T.h. (2013). Quality of Property Management Service Public Educational Buildings in Nigeria. Mediterranean Journal of Social Sciences, 4(2): 753-759.

Nwanekezie, F. O., Ifekalam, I.C, and Diala, O.A. (2009). An Assessment of Client Satisfaction with the Services of Estate Surveyors and Valuers in the Niger Delta. Abia State University Environmental Review, 7(1): 7795.

Oluwunmi, A.O., Ajayi, C.A., Olaleye, A. and Fagbenle, O.I. (2011). An Analysis of Clients' Satisfaction with Mortgage Valuation Reports in Nigeria. International Journal of Marketing Studies, 3(2): 160-168.

Sokanu, V. (2017). Career Satisfaction. Available at http//www.soleanu.com/anaytics/career-satisfaction retrieved on $18 / 11 / 2017$.

Spurk, D., Abele, A.E.. and Volmer, J. (2011). The Career Satisfaction Scale: Longitudinal Measurement Invariance and Latent Growth Analysis. Journal of Occupational and Organizational Psychology, 8(1): 315 326.

Woodcock, B. (2017). What makes us Happy at work? Available at https.www.kent.ac.uh/careers/chosing/careersatisfaction.htm retrieved on 18/11/2017. 